\title{
To What Extent Is Killing in Defence of Property Equal to Right to Life in Nigeria?
}

\author{
Igwe Onyebuchi Igwe \\ Faculty of Law, Ebonyi State University, Abakaliki, Nigeria \\ Email: igwelaw2010@gmail.com
}

How to cite this paper: Igwe, I. O. (2020).

To What Extent Is Killing in Defence of Property Equal to Right to Life in Nigeria? Beijing Law Review, 11, 1-10. https://doi.org/10.4236/blr.2020.111001

Received: September 25, 2019

Accepted: December 31, 2019

Published: January 3, 2020

Copyright $\odot 2020$ by author(s) and Scientific Research Publishing Inc. This work is licensed under the Creative Commons Attribution International License (CC BY 4.0).

http://creativecommons.org/licenses/by/4.0/

\begin{abstract}
Over the years, successive constitutions of the Federal Republic of Nigeria have included in their provisions defence of property as a permissible derogation to the right to life in Nigeria. This defence as exception to the right to life appeared to pay host to debates of scholars as to the propriety of equating killing in defence of property to right to life in Nigeria. This paper was commenced by a careful review of Nigerian law on right to life for the purpose of identifying areas that Nigerian law falls below international benchmark for the protection of the life of human person. It was discovered that the major challenge to the protection of right to life in Nigeria has been the lacunae in the Nigerian law. The provisions of Nigerian constitution with regard to the derogations of right to life fall short of global trend on the protection of right to life. A careful review of the problems shows that there is the need for Nigerian constitution to be amended to delete some limitation clauses on the full realisation of right to life in Nigeria.
\end{abstract}

\section{Keywords}

Right to Life, Defence of Property, Constitution, Nigeria

\section{Introduction}

This paper is set to discussing the extent a defence of property can exonerate a person for killing of another in Nigeria. The controversy that has remained unabated is the imperativeness of equating killing in defence of property to right to life in Nigeria. In order to resolve this issue, it has become germane to examine the provisions of the Constitution of the Federal Republic of Nigeria 1999 (as amended) and other relevant laws on the issue. The purpose of which is to identify areas which Nigerian law falls below international benchmark for the protection of right to life of individuals. 
It is germane to point it out that the inhumane treatment of the entire populations in concentration camps during the Second World War resulted in the widespread demand for the respect for human rights as the basis of international peace and progress. One major result was the proliferation of international treaties and instruments that placed obligations on nation states to treat their citizens with respect and to accord them rights. A state was no longer free to treat her citizens anyhow she likes. This emerging posture countered the previously held view that individuals were not the subject of international law, Okpara, (2008). ${ }^{1}$

The notion of individuals not being the subject of international law faded away with the Second World War. Today, the world in which we live is now referred to as a global village. The recognition and respect for human rights especially right to life is no longer the concern of the individual nations. The international community is interested and has taken steps to ensure that standards of the civilised community are adhered to. And it is these standards that define largely, the right of inclusion in the comity of nations, Shaw, (1991). ${ }^{2}$

In order to ensure that Article 55 (c) ${ }^{3}$ of the Charter of the United Nations ${ }^{4}$ is implemented, the Universal Declaration of Human Rights was adopted and proclaimed on the $10^{\text {th }}$ day of December, 1948 by the United Nations General Assembly. ${ }^{5}$ This was followed by other international treaties and legal instruments for the protection of human rights. Most of these treaties and legal instruments have been ratified by member states of the United Nations including Nigeria.

The Universal Declaration of Human Rights is the United Nations' grundnorm on human rights. The Declaration was intended not as a legally binding document; but its preamble proclaims: "a common standard of achievement for all peoples and nations." The Declaration consists of a preamble and 30 articles. It sets forth the human rights and fundamental freedoms to which all men and women, everywhere in the world, are entitled, without any discrimination. ${ }^{6} \mathrm{Ar}$ ticle 3 provides for right to life among other civil and political rights.

Although the Universal Declaration of Human Rights is not a legally binding document, it has become one of the best known and benchmark documents on the development of human rights in the world. The Declaration has had a marked influence on the constitutions of many states and on the formulation of subsequent human rights treaties and resolutions. The 1968 Proclamation of Tehran at the conclusion of the UN sponsored international conference on $\mathrm{Hu}$ man Rights stressed that the Declaration is a common understanding of the ${ }^{1}$ O Okpara (2008), Lecture Notes on the International Protection of Human Rights, 26, October, 2008. ${ }^{2}$ MN Shaw (1991), International Law (4 ${ }^{\text {th }}$ Ed., Cambridge: Grotius Publication, 1991) p. 206. ${ }^{3}$ The United Nations Charter, article 55(C) provides for the universal respect for and observance of Human rights and fundamental freedoms for all without "distinction" (emphasise mine).

${ }^{4}$ The United Nations Charter was signed by 45 Member States present at the Conference of San Francisco California, USA on the $25^{\text {th }}$ June, 1945.

${ }^{5}$ The United Nations General Assembly Resolution 217 A (III) of $10^{\text {th }}$ December, 1948.

${ }^{6} \mathrm{All}$ men and women in the context of the Declaration include those in prison custodies. 
peoples of the world concerning the inalienable and inviolable rights of all members of the human family and constitutes an obligation for the members of the international community. ${ }^{7}$ The conference reaffirmed its faith in the principles set forth in the Declaration and urged all peoples and governments to dedicate themselves to those principles and to redouble their efforts to providing for all human beings a life consistent with freedom and dignity and conducive to physical, mental, social and spiritual welfare. ${ }^{8}$

The Universal Declaration of Human Rights gave birth to the international covenants on civil and political rights, and the international covenants on economic, social and cultural rights. Subsequently the civil and political rights under the Universal Declaration of Human Rights were captured in Nigerian constitutions of 1963, 1979 and 1999 as enforceable rights. Among these enforceable rights under the Nigerian constitution is right to life. This right stands as primus inter pares.

In appreciation of the subject under discourse, an examination of the genesis of individual rights, meaning, right to life, property, the extent of defence of property to right to life in Nigeria among other issues will play premium. Recommendations and conclusion will be drawn at the end of the discussion.

\section{Right to Life}

Longman Dictionary of Contemporary English Language (Longman, 2007); ${ }^{9}$ defines life as the state of being alive as a human being. Right to life belongs to a person by virtue of his being born a human being, Igwe, (2017). ${ }^{10}$ In Genesis Chapter 2:7 the bible recorded thus "And the Lord God formed man of the dust of the ground and breathed into his nostrils the breath of life; and man became a living soul." ${ }^{\text {"11 }}$ Onyeka (2001) noted that "life is the sum total of human existence." ${ }^{\prime 2}$ Life is a gift from God. It is not given by the state. The state can only recognise and ensure not to impede its existence. Right to life is obviously the most fundamental of all human rights because other human rights can only be exercised by a person who is alive. ${ }^{13}$ It is supreme right of all human being.

According to Udu (2011), right to life is usually the first right guaranteed by every human rights instrument because of its fundamental in nature. ${ }^{14}$ In view of Omaka (2005) "the right to life is the most basic, the most fundamental, the

\footnotetext{
7"The Proclamation of Tehran, Final Act of the International Conference on Human Rights", $<$ https://undocs.org/A/CONF.32/41> accessed on $12^{\text {th }}$ February, 2016.

${ }^{8}$ The Tehran Proclamation, 1,2 and 3.

${ }^{9}$ Longman Dictionary of Contemporary English Language (New Edn, England: Pearson Publication, 2007) p. 820.

${ }^{10}$ I.O. Igwe, 2017, Prisoners' Rights in Nigeria: Challenges and Remedies (Enugu: Ecce Home and Pioneers Nig. Ltd, 2017) p. 132.

${ }^{11} J a m e s, 1979$, Holy Bible King James Version (Nashville, Tennessee: Holman Bible Publishers) p. 1.

${ }^{12}$ O.N. Onyeka (2001). Human Rights in Nigeria-Millennium Perspective (Lagos: Perfect Concepts, 2001) p. 31.

${ }^{13}$ O.N. Ogbu, 1999, Human Rights Law and Practice in Nigeria: an Introduction (Enugu: CIDJAP Press, 1999) p.83.

${ }^{14}$ E.A., Udu, 2011, Human Rights in Africa (Lagos: Mbeyi \& Associates (Nig) Ltd) p. 131.
} 
most primordial and supreme right which human beings are entitled to have and without which the protection of all other human rights becomes either meaningless or less effective." ${ }^{15}$ In Forum of Conscience v. Sierra Leone ${ }^{16}$ the African Commission on Human and People's Rights acknowledged that' the right to life is the fulcrum of all other rights. It is the fountain through which other rights flow.

Right to life is guaranteed by the Constitution of the Federal Republic of Nigeria, 1999 (as amended) ${ }^{17}$ hereinafter referred to as the "1999 Constitution" and African Charter on People's and Human Rights. ${ }^{18}$ While the African Charter does not clearly outline the circumstances by which an individual could be deprived of his life, the 1999 Constitution absolutely sets out the circumstances by which an individual could be deprived of his life in Nigeria. According to Obilade (2005), "since human freedom is part of human and human is a finite being, it follows that human freedom is necessary limited, for there can be no such thing as absolute or unlimited freedom (Garner, 2004)". ${ }^{19}$

\section{Property}

Black's Law Dictionary, (2004) defines property as "the right to possess, use, and enjoy a determinate thing (either a tract of land or chattel). ${ }^{20}$ Property donates "everything which is the subject of ownership, corporeal or incorporeal, tangible or intangible, visible or invisible, real or personal (Black, 1990)". ${ }^{21}$ Dadem (2012) describes property as an aggregate of rights belonging to a person which is guaranteed and protected. ${ }^{22}$ Section 2(1) of Conveyancing Act, 1881 provides that unless a contrary intention appears in any legislation, property include "real and personal property, any estate or interest in any property, real or personal, any debt, anything in action and any other right or interest." It is the right of a person to something tangible such as car, land, cloth (chose in possession) among others or something intangible such as intellectual investment in a work protected by a copyright (choose in action). In loose form, abstract objects such as atom, molecule, matter among others are said to have property. For this purpose, physicians always refer to property of a matter among others. But for the purpose of this discussion, the author's scope is limited to moveable and immo${ }^{15}$ C.A. Omaka, 2005. 'Rights to Life and to the Dignity of Human Person (Sections 33 and 34 of the 1999 Constitution) in O. Okpara ed. Human Rights Law \& Practice in Nigeria vol. 1 (Enugu: Chenlo Ltd, 2005) p. 112.

${ }^{16}$ [2000] AHRLR 293.

${ }^{17}$ Section 33 of the Constitution of the Federal Republic of Nigeria 1999 (as amended) provides for right to life.

${ }^{18}$ African Charter on People's and Human Rights has been domesticated in Nigeria by virtue of section 12 of the 1999 Constitution and it operates in Nigeria as African Charter on People's and Human Rights (Ratification and Enforcement) Act Cap A10 Laws of the Federation of Nigeria, 2004. See Article 2.

${ }^{19}$ A.O. Obilade, 2005, Ed, Legal Methods 1 (Ibadan: Jexel Commercial \& Security Printers) p. 18.

${ }^{20}$ B.A. Garner, 2004, Black's Law Dictionary Ninth Edition (USA: A Thomson Reuters Business), p. 1335.

${ }^{21}$ H.C. Black, 1990, Black's Law Dictionary $6^{\text {th }}$ Ed(USA: St. Paul Minn. West Publishing Co.,) p. 1216.

${ }^{22}$ Y.Y. Dadem, 2012, Property Law Practice in Nigeria $2^{\text {nd }}$ edn. (Jos: Jos University Press Ltd) p. 1. 
veable property as protected by the Constitution of the Federal Republic of Nigeria 1999 (as amended).

The right of a man to protect his property from invasion or appropriation by another is recognised under native law and custom as well as the English law and statutes. Pollock (2013) noted that the right to protect "one's castle is a time-honoured right that existed before the common law and was recognised by it." ${ }^{23}$ In the same vein, a combine reading of sections 43 and 44 of the Constitution of the Federal Republic of Nigeria 1999 (as amended) shows that individual's right to acquire, own or have interest in moveable and immoveable property is protected in Nigeria.

Awa argued that property interests that are traditionally protected by individual are possession of moveable property against theft or robbery and intrusion of immoveable property against trespass or unlawful invasion. ${ }^{24}$ The defence of property under the constitution may include the use of force to prevent a thief from taking moveable property or infliction of harm in order to prevent damage to property. The use of force reasonably necessary in defence of property that may result in the killing of the trespasser or an intruder into one's property is a permissible defence under the Nigerian constitution.

\section{Research Method}

In order to appreciate the topic under discourse, the research adopted a doctrinal research method. By this method, a careful review of Nigerian law on right to life and defence of property as one of exceptions thereto was carried out with a view to identifying areas that Nigerian law falls below the international benchmark for protection of the life of human person. This was achieved by utilising primary and secondary sources of materials such as the Constitution of the Federal Republic of Nigeria 1999 (as amended), case laws, textbooks and journal articles.

\section{Defence of Property as Limitation to Right to Life in Nigeria}

One of the circumstances set out under the 1999 Constitution as limitation to right to life is the defence of property. For this purpose, section 33 (2) (b) provides that:

A person shall not be regarded as having been deprived of his life in circumstances of this section, if he dies as a result of the use, to such extent and in such circumstances as are permitted by law, of such force as is reasonably necessaryfor the defence of any person from unlawful violence or for defence of proper$t^{25}$

From the above constitutional provision, it is beyond doubt that one of the

${ }^{23}$ J.M. Pollock, 2013, Criminal Law 10 th edn (USA: Anderson Publishing Waltham, 2013) p. 161.

${ }^{24}$ L.T Awa, "Killing in Defence of Property: A Legal Comparative Study" being a Masters Degree Thesis submitted to University of South Africa <http://hdl.handle.net/10500/21137>.

${ }^{25}$ Italics mine. 
exceptions to right to life in Nigeria is killing in defence of property. This averment is corroborated by the dictum of Muhammad Uwais in Musa v. State ${ }^{26}$ where he held among others that "by virtue of section $30^{27}$ of the 1979 Constitution, a person is even entitled to kill in the defence of his property provided he uses reasonable force in the circumstance."

Garrett (2017) noted that: "The concept of reasonableness pervades constitutional doctrine. The concept has long served to structure common-law doctrines from negligence to criminal law, but its rise in constitutional law is more recent." ${ }^{28}$ The concept of reasonableness that courts accept differs with judges. Judges apply competing objective or subjective test. ${ }^{29}$ Judges obviously employ a constitutional reasonability to measure defence in obtaining relief for the infringement of a constitutional right. The phrase "reasonable force" introduced by the draftsman of the 1999 Constitution in killing to protect one's property has given leeway to constitutional anarchy. This blank cheque provision has created more confusion than the draftsman of the 1999 Constitution intended to solve. The concept of reasonableness has been a subject of controversy in the legal jurisprudential journey.

Mendie, (2014) queried this constitutional provision when he lamented thus: "Our Constitution also allows the use of force as is necessary by one, in the killing of another in defence of his property." ${ }^{30}$ In the same vein, Ajomo (1992) argued that "... the blanket derogation from the right to life in matters relating to defence to property ... may need to be reviewed, if life is to have real meaning." ${ }^{31}$

What disturbs the mind of scholars is the extent of parameter for measuring circumstance that could be justified as reasonable force to kill human being in defence of one's property? Can any property be equated to human life? To worsen the scenario, the Constitution of the Federal Republic of Nigeria that provides for the application of reasonable force to kill in defence of property could not offer a single explanation of what force is reasonable under the constitution. This lacuna is left to be filled up at the whims and caprices of the court. And because judges are human beings, the test of reasonability depends on their orientation and background. In Ahmed v The State ${ }^{32}$ the Supreme Court held that granted that the accused killed the deceased in defence of his property, the force and weapons used by the accused persons were quite disproportional to the nature of the property.

The ambiguity associated with the constitutional concept of reasonableness pose danger to sacrosanctness of right to life. Hence, the need for a paradigm ${ }^{26}$ [1993] 2 NWLR (Pt. 277) p.550 at 553.

${ }^{27}$ Similar provision is in section 33 of the 1999 Constitution.

${ }^{28}$ B.L. Garrett, "Constitutional Reasonableness" (2017) Minnesota Law Review 102: 61.

${ }^{29}$ Ibid.

${ }^{30}$ A. Mendie, "Limitation of Human Rights: Right to Life under Nigerian Constitution, 1999 with Focus on Rural Women in Akwa Ibom State", Mediterranean Journal of Social Sciences vol.5 No 26 (Rome-Italy: MCSCR Publishing) p.156.

${ }^{31}$ M.A Ajomo, 1992, “Fundamental Rights under the Nigerian Constitution” in C. Akpamgbo ed., Perspectives in Human Rights (Lagos: Federal Ministry of Justice of Nigeria) p. 81.

${ }^{32}$ [1998] 5 NWLR (Pt. 550) p. 493. 
shift. The ambiguity lies in the measurement of the standard of the person who acted, the circumstance and the life lost in the exercise of reasonable act in defence of property. No matter the value of a property, it can never be equated to life. Awa agreed with this assertion when he posited thus: "A point of interest here is whether a situation can ever exist where the killing of an offender will be found to be proportionate to the value of the property sought to be protected." 33

In the words of Ogbu (2013), "A pertinent question is whether the provision permitting killing in defence of property reflects our cultural value. In other words, in our value preferences, does property come before life? The answer to the question is obviously in the negative,. In Africa and Nigeria in particular, life is valued over and above every other thing. Consequently, any permissible qualification of the right to life ought to be absolutely necessary for the defence of another life, or for the security of the society." 34

\section{The Need for Paradigm Shift}

A move away from the constitutional concept of reasonable force to kill in defence of property will put Nigeria on the track of solving some internal conflicts. On the other hand, if the clause, "reasonable necessary" must be retained, a definite step must be taken to explicitly, define such force or forces which may be reasonable in the context. This is because, to allow the determination of what force is reasonable in the hand of the court, is to the accused at the mercy of the judge. Property is replaceable but life lost cannot be replaced. Property cannot in any circumstance be valued more than life. Life is very fundamental and treated with sanctity. God the creator hates spilling of blood in any circumstance including killing in the guise of reasonable defence to one's property.

In African culture, killing of one by another is a very grievous offence not only against the collective interest of the society but also a contravention of divine law. Oraegbunam (2010) noted that "Life is believed to come from God. Therefore, any shedding of another's blood under any circumstance is an abomination (alu)." ${ }^{35}$ Although killing of one by another may be permitted in the time of war in African custom, however, those who killed in the time of war will be required to undergo through the ceremony of ritual cleansing after the war has ended. Okafor (1992) noted that in Igboland, if a villager kills another man, the murderer is expected to hang himself for "there is no provision for the public or private execution of murderer in Igboland." 36 According to him, if the murderer refuses to hang himself;

\footnotetext{
${ }^{33}$ L.T. Awa, "Killing in Defence of Property: A Legal Comparative Study" being a Masters Degree Thesis submitted to University of South Africa $<$ http://hdl.handle.net/10500/21137 $>$.

${ }^{34}$ O.N. Ogbu, 2013. Human Rights Law and Practice in Nigeria, $2^{\text {nd }}$ Revised edn vol. 1 (Enugu: Snaap Press Nigeria Ltd, 2013) p. 138.

${ }^{35}$ Ikenga K.E. Oraegbunam (2010) "Crime and Punishment in Igbo Customary Law: the Challenge of Nigerian Criminal Jurisprudence” African Journals Online vol. 7

https://www.ajol.info/index.php/org/article/viewfile/ 57917/46285 accessed on Thursday, 8 August, 2019.

${ }^{36}$ F.U. Okafor, 1992, Igbo Philosophy of Law, (Enugu: Fourth Dimension Publishers Co. Ltd.) p. 42.
} 
The villagers may nonetheless exert serious psychological and social pressure on the murderer but cannot go beyond that, if murderer has fled, his family must also flee, and their property confiscated, whenever the murderer is caught, he will be made to hang himself to enable umu okpu (daughters of the land) perform their cleansing rites, izachapu ntu ochu (sweeping away the ashes of murder ...) failure to perform those rites has consequences which are dreaded on the villagers.

In African culture, murder case of any kind must be finally settled through expiatory sacrifices to the gods

Since it is believed that murder is first of all, an offence against the gods. As a result of the above, murder cases are not subjected to trial "because of the belief that human life is essentially outside human jurisdiction." ${ }^{37}$

Although the above practices under African native law and customs may appear to have fallen under the moral code because of the supremacy of the present day constitutions, the system was well entrenched in African culture before it was clamped-down by colonial law. Today, "reasonably necessary" force in defence of property is entrenched in the Constitution of the Federal Republic of Nigeria as exonerating defence for shedding of another's blood. What an unfortunate constitutional provision. Although the application of "reasonable necessary" force to kill another in defence of property is a permissible defence under the Nigerian law, the author is of the view that it is still unacceptable to kill wrongdoer merely for unlawful invasion or appropriation of property. Killing in defence of property is a legal issue that has not gone well in the society as the general public are yet to appreciate why property should be valued more than life.

It is in the light of the above that the paper recommends for a further amendment to Constitution of the Federal Republic of Nigeria 1999 by deleting the clause "reasonably necessary" in Section 33(2) as the criteria for killing another in defence to one's property. The paper recommends this because most civilised societies do not permit killing in defence of property any longer. For instance Article 2(2) of the European Convention on Human Rights which is in interterm with Section 33(2) of Constitution of the Federal Republic of Nigeria 1999 does not permit killing in defence of property.

\section{Conclusion}

The paper has tried to analyze the extent of defence of property in killing of another under the Constitution of the Federal Republic of Nigeria 1999 (as amended). It has also examined the genesis of the protection of individual rights, meaning of right to life, meaning of property, defence of property as exception to right to life in Nigeria and suggested the need for a shift in paradigm.

The crop of this paper is that human life is sacrosanct and is viewed as such under African culture. Shedding of human blood under any circumstance is a

${ }^{37}$ Oraegbunma, op cit. 
violation of divine law. As noted above, killing in defence of property even though provided under the Nigerian Constitution is at variance with Nigerian culture. As a result of the above, the paper recommends for further amendment to the Constitution of the Federal Republic of Nigeria 1999 (as amended) by deleting the last clause in Section 33(2) (b) which provides for killing in defence of property as a good defence in a murder charge. It is the view of the paper that this amendment if done by the National Assembly will go along the way to curtailing farmers/herders clashes in most part of Nigeria. It is the view of the author that killing in defence of property may no longer pass the test of the constitution of many nations because of the popular opinion pointing to the fact that the value of property can never outweigh the value of human life.

\section{Conflicts of Interest}

The author declares no conflicts of interest regarding the publication of this paper.

\section{References}

Ajomo, M. A. (1992). Fundamental Rights under the Nigerian Constitution. In C. Akpamgbo (Ed.), Perspectives in Human Rights Lagos: Federal Ministry of Justice of Nigeria (pp. 79-109). Lagos: Nigerian Institute of Advanced Legal Studies.

Awa, L. T. (n.d.). Killing in Defence of Property: A Legal Comparative Study. Masters Degree Thesis, Pretoria: University of South Africa.

Black, H. C. (1990). Black's Law Dictionary(6th ed.). St. Paul, MN: West Publishing Co.

Dadem, Y. Y. (2012). Property Law Practice in Nigeria (2nd ed.). Jos: Jos University Press Ltd.

Garner, B. A. (2004). Black's Law Dictionary (9th ed.). |Toronto: A Thomson Reuters Business.

Garrett, B. L. (2017). Constitutional Reasonableness. Minnesota Law Review, 102, 61. https://doi.org/10.2139/ssrn.2903598

Igwe, O. I. (2017). Prisoners' Rights in Nigeria: Challenges and Remedies. Enugu: Ecce Home and Pioneers Nigeria Ltd.

James, K. (1979). Holy Bible King James Version. Nashville, TN: Holman Bible Publishers.

Longman (2007). Longman Dictionary of Contemporary English Language (New ed.). London: Pearson Publication.

Mendie, A. (1999). Limitation of Human Rights: Right to Life under Nigerian Constitution, 1999 with Focus on Rural Women in Akwa Ibom State. Mediterranean Journal of Social Sciences, 5, 154-160.

Obilade, A. O. (2005). Legal Methods 1. Ibadan: Jexel Commercial \& Security Printers.

Okafor, F. U. (1992). Igbo Philosophy of Law. Enugu: Fourth Dimension Publishers Co. Ltd.

Okpara, O. (2008). Lecture Notes on the International Protection of Human Rights.

Ogbu, O. N. (1999). Human Rights Law and Practice in Nigeria: an Introduction. Enugu: CIDJAP Press.

Ogbu, O. N. (2013). Human Rights Law and Practice in Nigeria (Vol. 1, 2nd Revised ed.). 
Enugu: Snaap Press Nigeria Ltd.

Omaka, C. A. (2005). Right to Life and to Dignity of Human Person (Sections 33 and 34 of the 1999 Constitution). In O. Okpara (Ed.), Human Rights Law \& Practice in Nigeria (Vol. 1). Enugu: Chenglo Ltd.

Onyeka, O. N. (2001). Human Rights in Nigeria-Millennium Perspective. Lagos: Perfect Concept.

Oraegbunam, I. K. E. (2010). Crime and Punishment in Igbo Customary Law: The Challenge of Nigerian Criminal Jurisprudence. OGIRISI: A New Journal of African Studies, 7, 1-30. https://doi.org/10.4314/og.v7i1.57917 https://www.ajol.info/index.php/org/article/viewfile/57917/46285

Pollock, J. M. (2013). Criminal Law (10th ed.). Waltham, MA: Anderson Publishing Waltham. https://doi.org/10.4324/9781315721828

Shaw, M. N. (1991). International Law (4th Ed.). Cambridge: Grotius Publication.

Udu, E. A. (2011). Human Rights in Africa. Lagos: Mbeyi \&Associate Nigeria Ltd. 